\title{
利用GRACE-FO重力卫星探测2019年长汇中下游 极端干旱
}

再艳红 ${ }^{1,2}$, 钟敏 ${ }^{1,2 *}$, 陈威 $1,2,3$, 钟玉龙 ${ }^{4}$, 冯伟 ${ }^{1}$

1. 中国科学院精密测量科学与技术创新研究院, 大地测量与地球动力学国家重点实验室, 武汉 430077;

2. 中国科学院大学地球与行星科学学院, 北京 100049 ;

3. School of Earth Sciences, the Ohio State University, Columbus 43210, USA;

4. 中国地质大学(武汉)地理与信息工程学院, 武汉 430074

*联系人, E-mail: zmzm@asch.whigg.ac.cn

2020-04-05 收稿, 2020-08-24 修回, 2020-08-27 接受, 2020-09-22 网络版发表

国家自然科学基金(41774094)和湖北省自然科学基金杰出青年项目(2019CFA091)资助

摘要 2019年夏秋季长江中下游地区持续半年的极端干旱给当地的农业生产和生态环境带来了严重的影响. 目 前对于千旱程度的估计主要依赖于降水、蒸散发、径流和土壤含水量等参数的监测. GRACE/GRACE-FO重力 卫星通过探测全球地球重力场变化, 捕捉地表水、土壤水分和地下水储量变化信息, 从而跟踪全球范围的干旱事 件. 虽然利用GRACE和GRACE-FO卫星观测全球和区域陆地水储量变化取得了重大成就, 但利用重力卫星监测 干旱程度的研究依然较少. 因此基于GRACE/GRACE-FO卫星观测资料, 通过估计GRACE-DSI, 研究分析了2019 年夏秋季长江中下游地区的干旱强度及其时空分布. 结果表明: (1) GRACE-DSI很好地反映了2019年夏秋季长江 中下游地区持续干旱的发生、发展过程，其中极端干旱区域位于湖北东部、江西北部、安徽南部等区域; (2) 湖 北、江西、安徽和湖南四省区域平均的GRACE-DSI指数与 6 个月时间尺度的SPEI-Z的时间序列吻合最好, 相关 性为 0.84 , 说明GRACE-DSI能够反映干旱的长期积累效应; (3) 通过比较长江中下游区域2011年春夏和2019年夏 秋两次极端干旱事件的监测, 显示GRACE-FO与GRACE前后两组重力卫星具有等同的干旱监测能力. 今后随着 重力卫星观测的空间分辨率和时间分辨率的不断提高, GRACE-DSI将能够更为准确、快速地探测水文极端千旱 事件.

关键词 GRACE-FO重力卫星, GRACE-DSI, 千旱指数, 长江中下游

2019年夏秋季长江中下游区域(湖北、安徽、江 西、湖南)发生了持续半年的大干旱，对当地的农业生 产、生态环境、人们的日常生活产生了显著的影响. 干旱可以分为气象干旱、农业干旱、水文干旱、社会 经济干旱. 气象干旱是其他 3 种干旱的基础, 气象干旱 随时间持续发展，有可能导致土壤水分不足，江河径 流、湖泊水库水位和地下水位下降, 甚至影响人类生
活, 从而引发农业干旱、水文干旱、社会经济干旱. 传 统上, 监测干旱的主要手段是监测降雨量、蒸散发 量、土壤含水量、径流量等, 然后通过干旱指数量化 干旱程度. 常用的干旱指数有标准化降水指数SPI(standardized precipitation index)、标准化降水蒸散发指数 SPEI(standardized precipitation evapotranspiration index)、帕默尔干旱指数PDSI(Palmer drought severity

引用格式: 由艳红, 钟敏, 陈威, 等. 利用GRACE-FO重力卫星探测2019年长江中下游极端干早. 科学通报, 2021, 66: 107-117 Ran Y H, Zhong M, Chen W, et al. Monitoring the extreme drought in the middle and lower reaches of the Yangtze River in 2019 from GRACE-FO satellites (in Chinese). Chin Sci Bull, 2021, 66: 107-117, doi: 10.1360/TB-2020-0375 
index)、自矫正帕默尔干旱指数scPDSI(self-calibrating Palmer drought severity index)、标准化径流指数SRI (standardized runoff index)等. 这些干旱指数研究对象 及考虑的物理过程不同, 所需的变量和计算方法不完 全相同, 所以对同一干旱事件的监测结果可能存在较 大差异 ${ }^{[1]}$. 然而, 干旱的成因复杂, 除了自然因素, 还有 人为因素 ${ }^{[2,3]}$, 所以单纯地考虑一种或多种气象要素(如 降水量、蒸散发量), 并不能全面反映真实的干旱情形. 更为关键的是, 这些传统手段所用的数据大多为站点 数据, 存在站点分布不均, 区域数据贵乏的缺陷.

GRACE(Gravity Recovery And Climate Experiment)重力卫星自2002年3月发射, 对全球重力场变化 进行了长达 16 年的观测, 期间积累了丰富的观测数据 和数据应用经验. 利用GRACE卫星观测资料解算的月 重力场模型可以在 $300 \mathrm{~km} \times 300 \mathrm{~km}$ 的空间尺度上反映 地球重力场的变化, 并能达到相当高的精度 ${ }^{[4,5]}$. 该数据 被广泛应用于研究陆地水变化、南极和格陵兰岛冰盖 变化以及全球海平面变化等 ${ }^{[6]}$. 地球重力场的变化扣除 地壳物质移动、大气运动、洋流和潮汐等因素的影响 后, 可以反演陆地水文信号得到大尺度陆地水储量变 化. 目前这一技术已经在全球和区域陆地水储量研究 中得到广泛应用 ${ }^{[6-9]}$. 实践表明, 利用GRACE时变重力 场模型可探测中长空间尺度的陆地水储量变化趋势. GRACE监测的陆地水储量异常(terrestrial water storage anomaly, TWSA)是指地球陆地垂直方向上水储量的异 常，包括冰雪、地表水、土壤水以及地下水的异常 ${ }^{[10]}$. 此外, 自然和人为因素导致的陆地水储量异常都能被 GRACE有效监测 ${ }^{[11,12]}$. 因此, GRACE重力卫星具有监 测区域及全球干旱的巨大潜力 ${ }^{[13]}$.

近年来, 国内外学者在GRACE监测干旱方面开展 了一系列研究工作. Chen等人 ${ }^{[8]}$ 基于 GRACE资料较早 发现2005年亚马逊流域存在的流域性干旱. 冯伟等 人 $^{[6]}$ 进一步利用GRACE 监测到亚马逊流域2009年的洪 水与 2010 年的干旱. 此外, GRACE也成功用于监测全 球多个区域的干旱事件. Chen等人 ${ }^{[14]}$ 通过重力卫星观 测的陆地水储量变化研究了南美洲拉普拉塔流域 2002 2009年的干旱情况, 包括干旱的发生、发展、顶 峰等. Long等人 ${ }^{[15]}$ 通过GRACE数据和人工神经网络模 型，分析了 2003 年以来近 10 年中国西南部云贵高原干 旱洪涝灾害的发生频率和严重程度. 在此基础上, 部分 学者进一步基于GRACE资料建立了干旱指数来定量 评估干旱影响. Yirdaw等人 ${ }^{[16]}$ 利用GRACE监测的陆地 水储量变化时间序列计算得到总储量亏损指数(total storage deficit index, TSDI), 分析了2002 2003年加拿大 三省大草原(Canadian prairie)的干旱特征. Yi等人 ${ }^{[17]}$ 利 用基于 GRACE数据建立的水文干旱指数(GRACEbased hydrological drought index, GHDI)评估美国干旱, 发现其和传统帕默尔水文干旱指数(Palmer hydrological drought index, PHDI)具有良好相关性, 表明GHDI 在干旱监测方面具有很高的可行性. Zhao等人 ${ }^{[18,19]}$ 提 出GRACE干旱强度指数(GRACE-based drought severity index, GRACE-DSI), 对全球干旱强度进行评估, 并 与PDSI和SPEI等干旱指数进行比较后发现, GRACEDSI能有效监测全球和区域尺度的干旱事件. 在我国, Wang等人 ${ }^{[20]}$ 分析了中国海河流域的GRACE陆地水储 量、降水、增强型植被指数(enhanced vegetation index, EVI)及其对应的陆地水储量异常指数、降水异常指 数、植被异常指数, 表明GRACE资料适合探测海河流 域长期且强度较大的干旱. $\mathrm{CaO}$ 等人 ${ }^{[21]}$ 采用基于 GRACE计算的TSDI研究了中国西北地区的干旱动态, 这对缺乏地面气象观测资料相对缺乏的西北地区具有 重要意义. Sun等人 ${ }^{[13]}$ 采用GRACE资料获取的水储量 亏损(water storage deficit, WSD) 和水储量亏损指数 (water storage deficit index, WSDI)评估了长江流域长 达13年(2003 2015年)的干旱情况, 发现WSDI有助于对 大规模地区的干旱进行可靠描述. 以上研究均证实了 GRACE在监测评估全球和区域干旱方面的巨大作用.

2018年5月, 继GRACE重力卫星停止工作一年之 后, GRACE-FO(GRACE Follow-On)重力卫星成功发 射, 旨在延续GRACE卫星的科学观测任务. 本研究基 于GRACE-FO卫星观测数据, 利用GRACE-DSI研究 2019年7 12月长江中下游区域发生的极端干旱的发展 过程以及干旱强度, 并通过与SPEI进行对比, 分析研究 GRACE-DSI评估此次极端干旱的优劣. 另外, 由于 GRACE-FO双星之一的GRACE-D卫星用于测量非保 守力的关键载荷“加速度计”失灵, 那么基于模型进行 了数据修正的GRACE-FO卫星是否还具有GRACE卫 星监测区域干旱的能力也是本研究关心的科学问题 之一.

\section{1 数据来源及预处理}

\subsection{GRACE-TWSA}

本研究所用数据为CSR(Center for Space Research) 
提供的 2002 年 4 月 2017年6月共 163 个月的GRACE和 2018年6月 2019年12月共17个月的GRACE-FO Level2 (Release 06版)月重力场模型数据. 该数据截断阶数为 60 阶，并且扣除了非潮汐大气、非潮汐高频海洋信 号、海潮、固体潮和固体极潮等的影响. 该研究对 GRACE/GRACE-FO数据进行了以下预处理：(1) 用卫 星激光测距(satellite laser ranging, SLR)观测的 $C_{20}$ 项替 换GRACE/GRACE-FO的原始 $C_{20}$ 项 ${ }^{[22]}$; (2) 用联合卫星 重力数据和海洋模型输出的一阶项替换 GRACE/ GRACE-FO的原始一阶项 ${ }^{[23,24]}$; (3) 从 GRACE/GRACEFO球谐系数中扣除2004年1月 2009年12月 GRACE球 谐系数的平均值; (4) 采用Swenson等人 ${ }^{[25]}$ 提出的方法 去除球谐系数之间的相关性, 减少条带误差的影响; (5) 对去条带后的球谐系数进行 $300 \mathrm{~km}$ 高斯平滑，降低高 阶球谐系数的噪声 ${ }^{[26]}$; (6) 最后将球谐系数转化 为 $1^{\circ} \times 1^{\circ}$ 全球分布的等效水柱高格网数据，即获得了总 水储量异常TWSA ${ }^{[27]}$; (7) 用“尺度因子”的方法进行信 号泄漏误差改正 ${ }^{[28]}$. 需要说明的是, $1^{\circ} \times 1^{\circ}$ 并不反映 GRACE的真实分辨率，GRACE数据的实际空间分辨 率为 $300 \mathrm{~km}$ 左右 ${ }^{[5]}$ ，已有研究表明该尺度不影响大干 旱的监测 ${ }^{[16,18]}$. 后文为了方便表述，用GRACE-TWSA 表示由GRACE/GRACE-FO计算的TWSA. 需要注意的 是, 总水储量异常和陆地水储量异常的英文缩写均为 TWSA，两者区别主要在于，前者包括陆地和海洋，后 者仅包括陆地, 本文的研究区域仅考虑陆地, 所以后文 中TWSA专指陆地水储量异常.

为了更好地获取陆地水异常状况, 需要扣除TWSA 的季节项和趋势项, 研究年际项. 由于GRACE-FO观测 时间仅 17 个月且与 GRACE间有 10 个月的数据缺失，无 法直接用GRACE/GRACE-FO共 180 个月的数据解算出 季节项和趋势项. 为保证数据处理的统一性, 选用2005 年1月 2015年12月 (该时间段内GRACE工作状态良好) 的GRACE-TWSA解算, 并去除所有月份陆地水储量异 常的季节项和趋势项.

\subsection{GRACE-DSI}

本研究选用GRACE-DSI对干旱强度进行量化，其 计算公式如下 ${ }^{[18,19]}$ :

$\operatorname{GRACE}-D S I_{i, j}=\frac{\text { TWSA }_{i, j}-\mathrm{TWSA}_{j}}{\sigma_{j}}$,

其中， $i$ 表示年(2002 2019年)； $j$ 表示月(1 12月);
TWSA $_{j}$ 和 $\sigma_{j}$ 分别表示 $j$ 月陆地水储量异常的平均值和标 准差. 为了方便表述，用GRACE-DSI表示由GRACE/ GRACE-FO计算的干旱指数. 与Zhao等人 ${ }^{[18,19]}$ 的计算 不同，本研究考虑到TWSA季节项和趋势项对陆地水 异常状况的影响，在计算GRACE-DSI时，去除了 TWSA的趋势项和季节项. GRACE-DSI是一个无量纲 值，可用于监测干旱洪涝. 本研究GRACE-DSI将干旱 洪涝分为 9 种类型, 参照SPEI的分级标准 ${ }^{[29]}$, 如表 1 .

\subsection{SPEI}

干旱指数目前广泛使用的有十几种，影响力比较 大的包括1965年Palmer ${ }^{[30]}$ 创建的PDSI指数、1993年 $\mathrm{McKee}$ 等人 ${ }^{[31}$ 提出的SPI指数，以及 2010 年Vicente-Serrano等人 ${ }^{[29]}$ 提出的SPEI指数. PDSI指数是一种物理化 的干旱指数, 基于计算两层土壤水平衡状况, 与SPEI指 数、SPI指数这类统计干旱指数不同, Palmer ${ }^{[30]}$ 提出了 气候适宜态(climatically appropriate for existing conditions)的概念. 标准化降雨指数SPI由降雨在不同时间尺 度上的累计和计算而来 ${ }^{[31]}$. SPEI在SPI的基础上引人潜 在蒸散发、温度的信息，由降雨和潜在蒸散发的差值 在不同时间尺度上的累计和计算而来 ${ }^{[29]}$. SPEI指数与 SPI指数类似，具有多尺度时间的特性 ${ }^{[32]}$ ，两类指数都 能识别不同类型的干旱及干旱对不同系统(包括气 象、水文、农业、生态等)的影响 ${ }^{[33]}$. PDSI、SPEI、 SPI等指数各有优劣，但在大尺度上很难获得确定性的 结论 ${ }^{[34]}$. 由于数据获取的及时性问题, 本研究仅选择 SPEI指数与GRACE-DSI的时空变化进行对比.

本研究使用的SPEI是来自网站https://spei.csic.es/ 的 $1^{\circ} \times 1^{\circ}$ 格网数据集. 计算该数据集所用的降雨数据来 自全球降雨气候中心(Global Precipitation Climatology Centre，GPCC), 潜在蒸散发由美国国家海洋和大气管 理局(National Oceanic and Atmospheric Administration, NOAA)提供的温度数据及Thortnth-waite方程计算.

为保证数据的时空一致性, 本研究对 GRACE/ GRACE-FO数据相同时段(2002年4月 2019年12月)的 SPEI数据进行GRACE/GRACE-FO数据相同的处理, 包 括: 转化为球谐系数、截断到与卫星重力相同的 60 阶 球谐系数(即与GRACE-TWSA相同的 $300 \mathrm{~km}$ 分辨率)、 用Swenson等人 ${ }^{[25]}$ 提出的方法去除相关性、 $300 \mathrm{~km}$ 高 斯平滑、转化为 $1^{\circ} \times 1^{\circ}$ 格网数据、去除趋势项和季节 项. 最后标准化SPEI的 $1^{\circ} \times 1^{\circ}$ 格网数据为SPEI-Z, 标准 化公式如下: 
表 1 GRACE-DSI和SPEI-Z的干湿等级分级标准

Table 1 Classification standard for wet and dry conditions of GRACEDSI and SPEI-Z

\begin{tabular}{cc}
\hline GRACE-DSI、SPEI-Z & 干旱类型 \\
\hline$<-2.0$ & 极端干旱 \\
$-2.0 \sim-1.5$ & 重度干旱 \\
$-1.5 \sim-1.0$ & 中度干旱 \\
$-1.0 \sim 0$ & 轻度干旱 \\
0 & 正常 \\
$0 \sim 1.0$ & 轻度湿润 \\
$1.0 \sim 1.5$ & 中度湿润 \\
$1.5 \sim 2.0$ & 重度湿润 \\
$>2.0$ & 极端湿润 \\
\hline
\end{tabular}

$S P E I-Z_{i, j}=\frac{S P E I_{i, j}-\overline{S P E I}_{j}}{\sigma_{j}}$,

其中, $\sigma_{j}$ 表示 $j$ 月 SPEI的标准差.

\section{4 全国气象干旱综合指数}

本研究使用的全国气象干旱综合指数来自网站 https://cmdp.ncc-cma.net/nccdownload，时间分辨率为 日. 气象干旱综合指数是以标准化降水指数、相对湿 润指数和降水量为基础建立的一种综合指数. 该指数 考虑了 $60 \mathrm{~d}$ 内的有效降水(权重累计降水)、30 d内蒸散 (也是相对湿润度)以及季度尺度 $(90 \mathrm{~d})$ 降水和近半年尺 度(150 d)降水的综合影响, 具体计算公式如下:

$$
\begin{aligned}
\mathrm{MCI}= & K a \times\left(a \times \operatorname{SPIW}_{60}+b \times \mathrm{MI}_{30}\right. \\
& \left.+c \times \mathrm{SPI}_{90}+d \times \mathrm{SPI}_{150}\right),
\end{aligned}
$$

其中, MCI表示气象干旱综合指数; $\mathrm{MI}_{30}$ 表示近 $30 \mathrm{~d}$ 相 对湿润度指数; $\mathrm{SPI}_{90}$ 表示近 $90 \mathrm{~d}$ 标准化降水指数; $\mathrm{SPI}_{150}$ 表示近 $150 \mathrm{~d}$ 标准化降水指数; $\mathrm{SPIW}_{60}$ 表示近 $60 \mathrm{~d}$ 标准化权重降水指数; $a$ 是 SPIW $_{60}$ 的权重系数, 北方及 西部地区(我国西北、东北、华北和西南地区等)取 0.3 , 南方(我国华南、华中、华东地区等)取 $0.5 ; b$ 是 $\mathrm{MI}_{30}$ 的 权重系数, 北方及西部地区取 0.5 , 南方取 $0.6 ; c$ 是 $\mathrm{SPI}_{90}$ 的权重系数, 北方及西部地区取 0.3 , 南方取 $0.2 ; d$ 是 $\mathrm{SPI}_{150}$ 的权重系数, 北方及西部地区取 0.2 , 南方取 $0.1 ; \mathrm{Ka}$ 为季节调节系数，根据不同季节各地主要农作 物生长发育阶段对土壤水分的敏感程度是确定的.

因此，该指标既反映短时间尺度(月)和长时间尺度 (季)降水量气候异常情况，又反映短时间尺度(影响农
作物)水分亏欠情况. 该指数适用于作物生长季逐日气 象干旱的监测和评估. 本研究以全国气象干旱指数的 每月平均值代表当月干旱情况，与GRACE-TWSA进行 对比分析.

\section{2 结果与分析}

2019年7月下旬以来，鄂湘赣苏皖浙闽等七省大部 地区降水较常年同期偏少2 8成, 其中湖北与江西地区 偏少 8 成以上，湖北、江西均为 1961 年以来历史同期最 少, 安徽为同期第二少. 由于持续高温少雨, 长江中下 游地区气象干旱迅速发展, 此次持续半年的极端干旱 (图S1), 发展历程分为两个阶段: 第一阶段为7月下旬 至11月中旬, 湖北大部、湖南北部、江西北部、安徽 大部等地普遍有中到重度的气象干旱，其中湖北东 部、安徽南部有极端干旱; 第二阶段为 11 月下旬至 12 月底, 由于 11 月中下旬重度干旱区的两场降雨, 湖北东 部、湖南北部气象干旱有所缓解，但 12 月份江西南 部、广东大部等地降水较常年同期偏少 5 9成，旱情 持续.

\subsection{GRACE-TWSA陆地水储量变化}

GRACE-FO重力卫星观测的陆地水储量变化 (TWSA)包含趋势项、季节项、年际项等不同时间尺度 的信号, 其中趋势项和季节项对年际异常信号的甄别影 响较大. 因此, 为了更好地显示此次长江中下游区域的 干旱信号, 本研究从GRACE-TWSA变化信号中扣除了 趋势项和季节项变化信号, 得到它的年际信号(图1).

图1显示了GRACE-FO重力卫星观测的2019年 7 12月中国陆地水储量年际变化信号(月均值)的空间 分布. 如图1(a)所示, 2019年7月, GRACE-TWSA陆地水 年际信号呈现明显亏损的区域相对较少, 强度也较弱, 主要分布在河北、山东、河南北部等区域. 2019年8 月，陆地水亏损区域整体向南迁移至湖北、湖南、江 西、安徽、浙江、江苏等区域(图1(b)). 图1(c)显示, 2019年9月, 该区域GRACE-TWSA的亏损程度加剧, 亏 损范围扩大. 截至2019年10月, GRACE-TWSA年际信 号亏损范围进一步扩大至广西、河北南部等地(图 1 (d)). 图1(e)显示，2019年11月GRACE-TWSA年际信号 相比于10月, 亏损范围向南移, 具体表现为: 河南、河 北、安徽陆地水亏损缓解, 广东、福建陆地水亏损加 重. 2019年12月, 山东、江苏、河南、安徽北部陆地水 亏损持续缓解，而广东、福建等地陆地水亏损持续加 

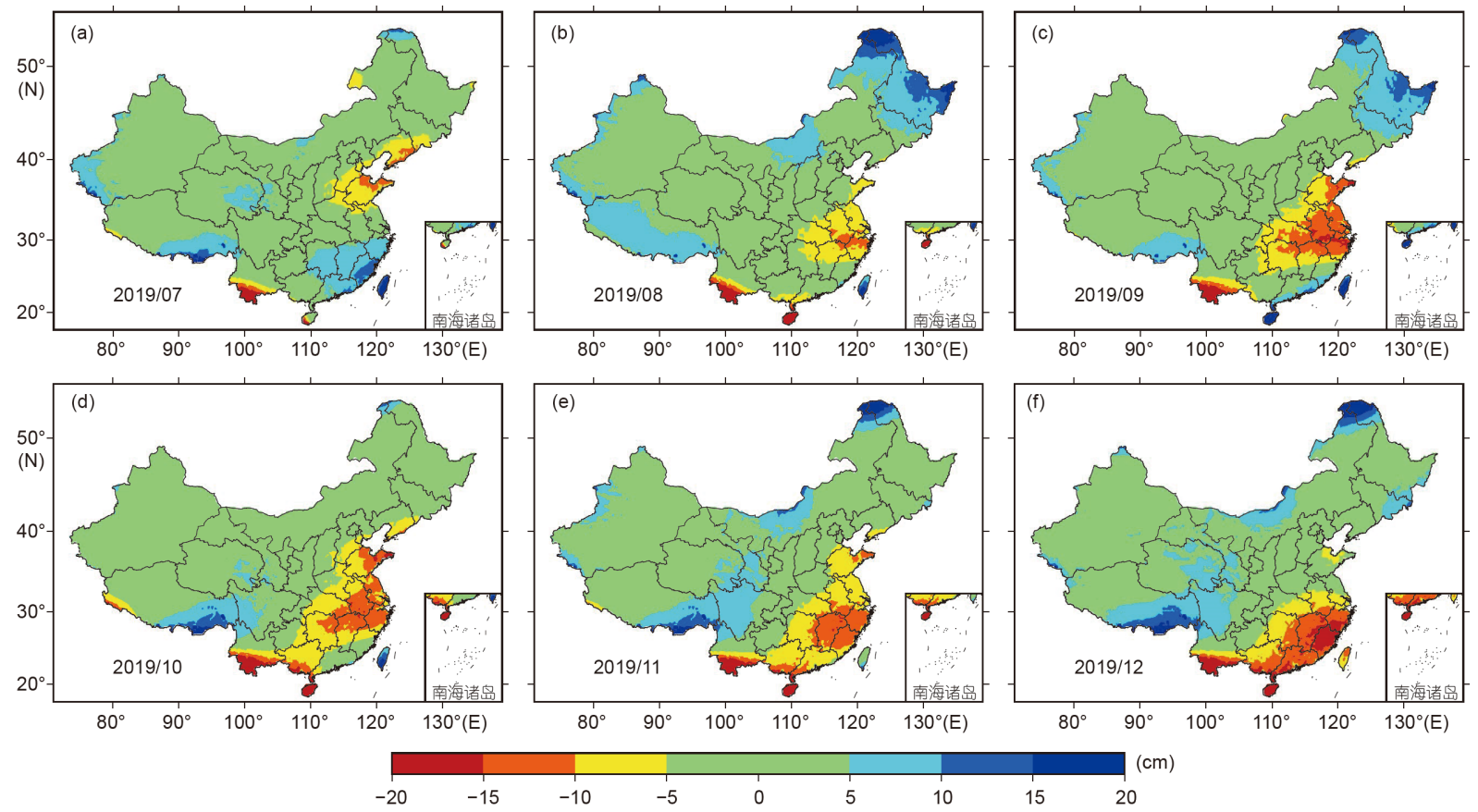

图 1 GRACE-FO重力卫星观测的2019年下半年中国陆地水储量异常的年际信号(扣除了趋势和季节项信号)

Figure 1 Spatial patterns of interannual terrestrial water storage anomaly (TWSA) from GRACE-FO over China in the second half of 2019 with seasonal cycles and trends removed

重, 亏损最明显区域集中在福建大部分区域, 亏损值最 大达到 $17.95 \mathrm{~cm}$ 等效水柱高. 图1清晰地展示了2019年 7 12月 GRACE-TWSA随时间的年际变化，与对应时间 内干旱的变化进程基本一致。但 2019 年 11 和 12 月 GRACE-TWSA陆地水亏损中心区域与同时期全国气 象干旱综合监测的结果有所不同, 后者干旱的中心区 域11月位于安徽、江苏、江西等地，12月份位于广东 和福建西部等地，且后者显示 12 月份湖北、江西、安 徽、湖南等地旱情大大缓解. 造成这种差别的原因主 要在于卫星重力手段监测所有水文成分(包括冰雪、 地表水、土壤水、地下水), 而后者主要监测当月降水. 在水循环过程中, 降雨可以转化为各个水文成分, 但这 个过程需要的时间存在很大差异 ${ }^{[31]}$.

\subsection{GRACE-DSI和SPEI-Z的空间分布}

由于GRACE-FO重力卫星观测结果存在条带误差, 需要进行去条带以及空间平滑处理, 导致卫星观测的 空间分辨率(半波长)为 $300 \mathrm{~km}$ 左右, GRACE-TWSA年 际变化信号的强度无法避免有所压制. 因此虽然能够 描述干旱的发生和发展过程, 但不能很好地量化干旱 的强度, 而GRACE-DSI可用来量化干旱的强度. 如式 (1)所示, GRACE-DSI是描述陆地水储量变化偏离其正
常变化的一个无量纲参数. 本研究通过估算每个月陆 地水储量年际变化信号偏离2002 2019年所有相同月 份变化信号平均值的程度, 得到GRACE-DSI. 通过这种 无量纲参数化, 可以消除陆地水量变化信号被压制带 来的不利影响. 图2显示了2019年下半年6个月中国大 陆区域的GRACE-DSI的空间分布. 从图2中可以看出, GRACE-DSI所显示的极端干旱区(指数 $<-2.0$ )大多分布 在长江中下游的湖北东部、安徽南部、江西北部等区 域(8 10、12月份)，9月份(图2(c))极端干旱区域的范围 最大, 7月份(图2(a))极端干旱区域位于安徽、山东、河 南交界区域且范围较小. GRACE-DSI 12月份干旱指数 (图2(d)) 显示极端干旱(指数 $<-2.0$ ) 依然发生在长江中下 游区域, 同时显示南方区域发生了重度干旱(指数小于1.5、大于-2.0). 而12月份的GRACE-TWSA显示了广 东、福建等地陆地水量亏损严重，但并不能反映该月 的干旱强度.

图3显示了2019年下半年中国SPEI06-Z的空间分 布. 通过对比分析各时间尺度的SPEI-Z指数(图3,S2)和 GRACE-DSI(图2)的空间分布, 发现SPEI06-Z和 GRACE-DSI显示干旱空间分布随时间变化较为一致. 两者均显示长江中下游的干旱始于 8 月, 9 月加重, 10 、 11月持续有缓解, 但 12 月仍加重. SPEI01-Z(图S2)总体 

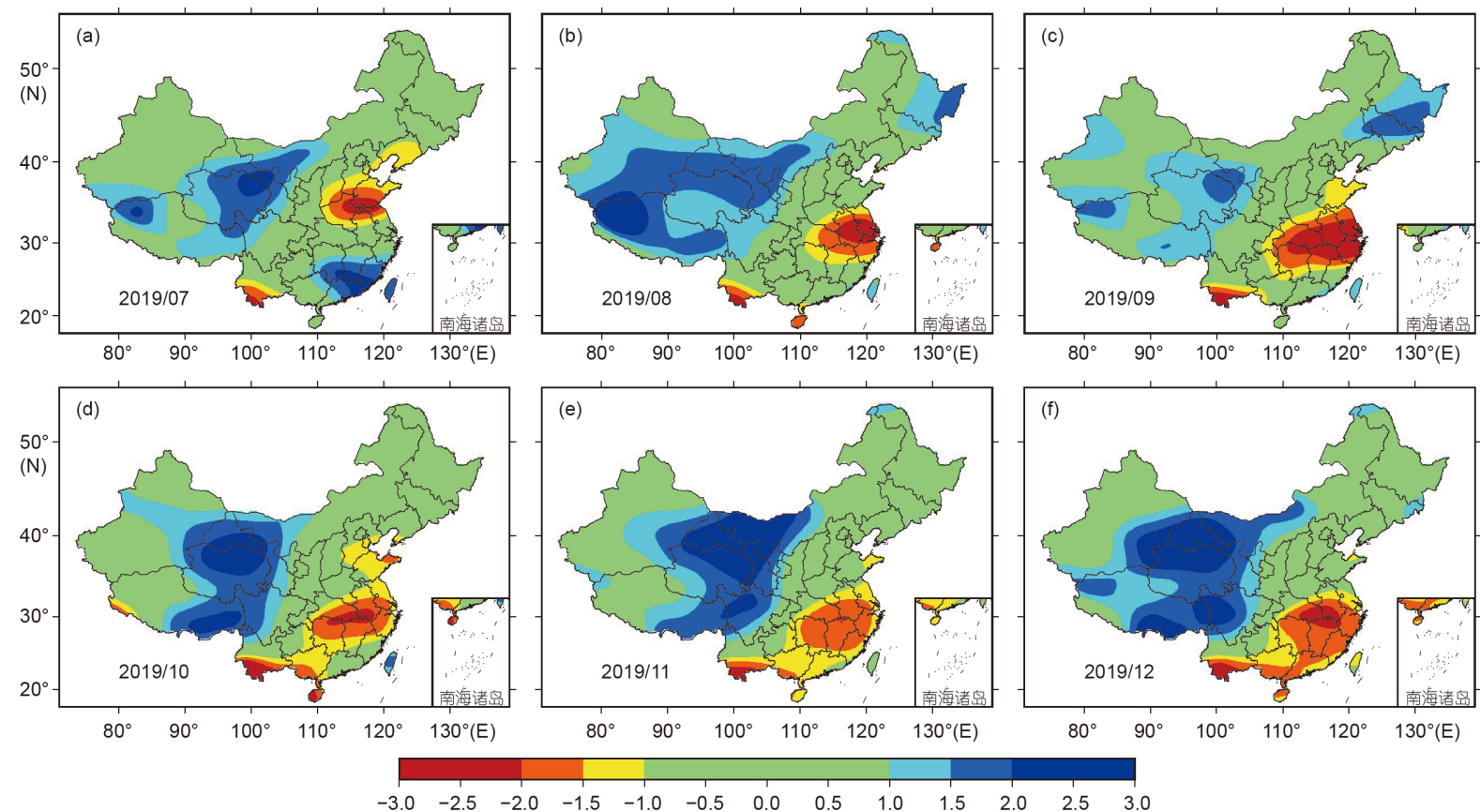

$\begin{array}{lllllllllllll}-3.0 & -2.5 & -2.0 & -1.5 & -1.0 & -0.5 & 0.0 & 0.5 & 1.0 & 1.5 & 2.0 & 2.5 & 3.0\end{array}$

图 2 2019年7 12月份中国GRACE-DSI的空间分布

Figure 2 Spatial patterns of GRACE-DSI in China from July to December 2019
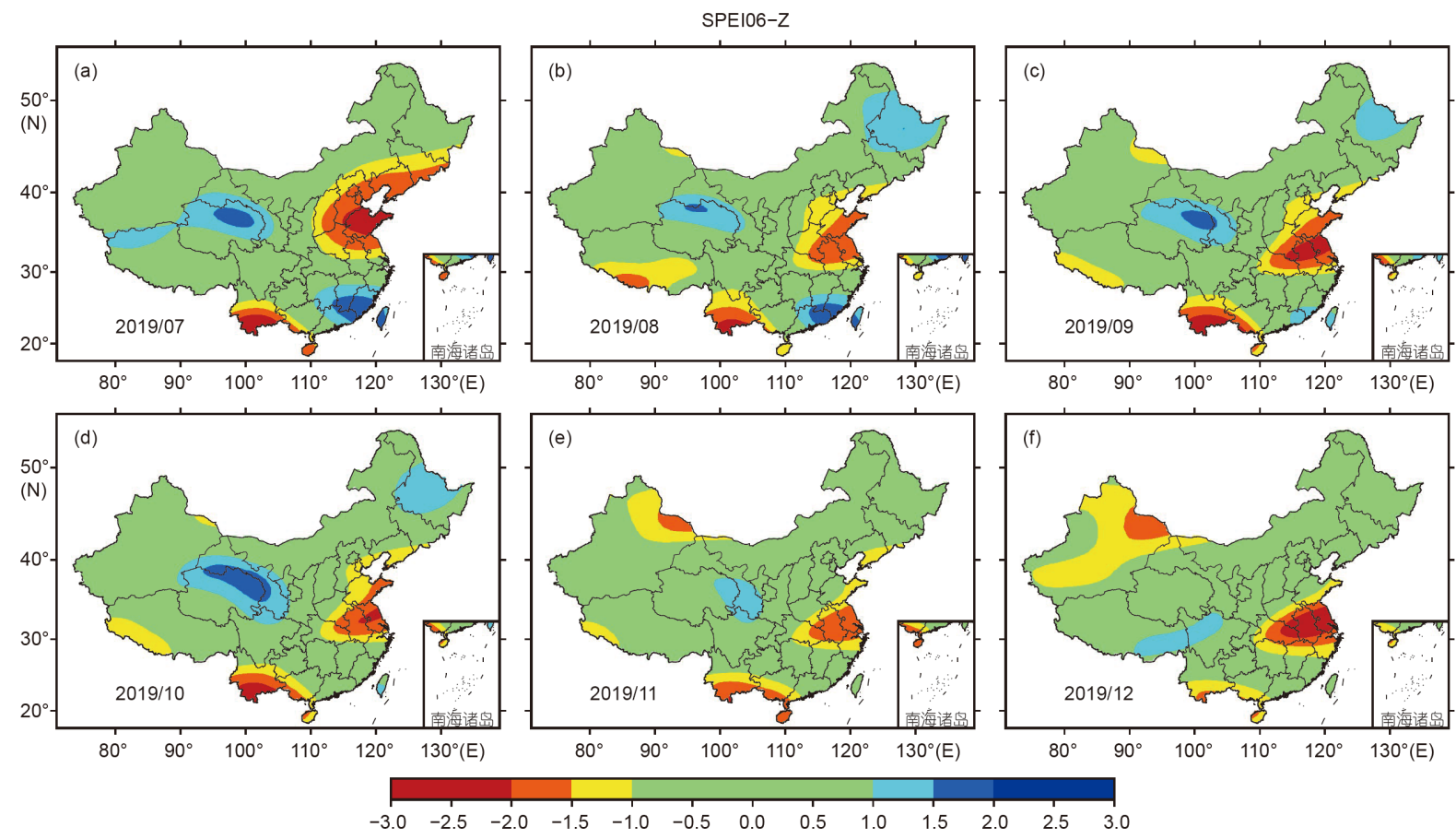

图 32019 年7 12月份中国SPEI06-Z的空间分布

Figure 3 Spatial patterns of SPEI06-Z in China from July to December 2019

上反映了 2019年7 9月份干旱发生、发展过程的空间 分布, 与GRACE-DSI一样, 显示出湖北东部、安徽南
部、江西北部、湖南北部8、9月的极端干旱，除了干 旱强度有差异，两者基本上一致. 但2019年10 12月份 
SPEI01-Z与GRACE-DSI空间分布, 差别明显. SPEI03-Z (图S2)的空间分布显示了长江中下游区域10、11月份 的强度和极端干旱信号, 且11月较10月强度加重，与 GRACE-DSI的空间分布特征有差异. SPEI 09-Z/SPEI 12-Z(图S2)的空间分布显示了2019年下半年的重度或 极端干旱区域大都位于长江偏北区域，而SPEI24-Z的 空间分布则显示2019年下半年湖北、安徽、江西、湖 南交界处有重度干旱。通过大量对比分析发现，SPEI06显示的干旱空间分布变化和GRACE-DSI符合较好. 主要原因在于，GRACE-DSI反映水文系统全水文成分 (包括冰雪、地表水、土壤水、地下水)的干旱情况， SPEI-Z反映不同时间尺度上降雨和蒸散发的差值，而
水文成分对水量平衡的响应时间一般随着水分的人渗 过程而延长 ${ }^{[18]}$.

综合GRACE-DSI和各个时间尺度SPEI-Z的空间分 布来看，两者均能反映2019年下半年长江中下游地区 的干旱. GRACE-DSI和6个月时间尺度的SPEI-Z的干 旱空间分布变化符合相对较好，这说明GRACE-DSI反 映了水分短缺的长期积累效应.

\subsection{GRACE-DSI和SPEI-Z的时间序列}

为了进一步验证GRACE-DSI的特性，本研究还选 用各个时间尺度( $1 、 3 、 6 、 9 、 12 、 24$ 个月)SPEI-Z的 时间序列与之进行对比。通过观察前面的GRACE-
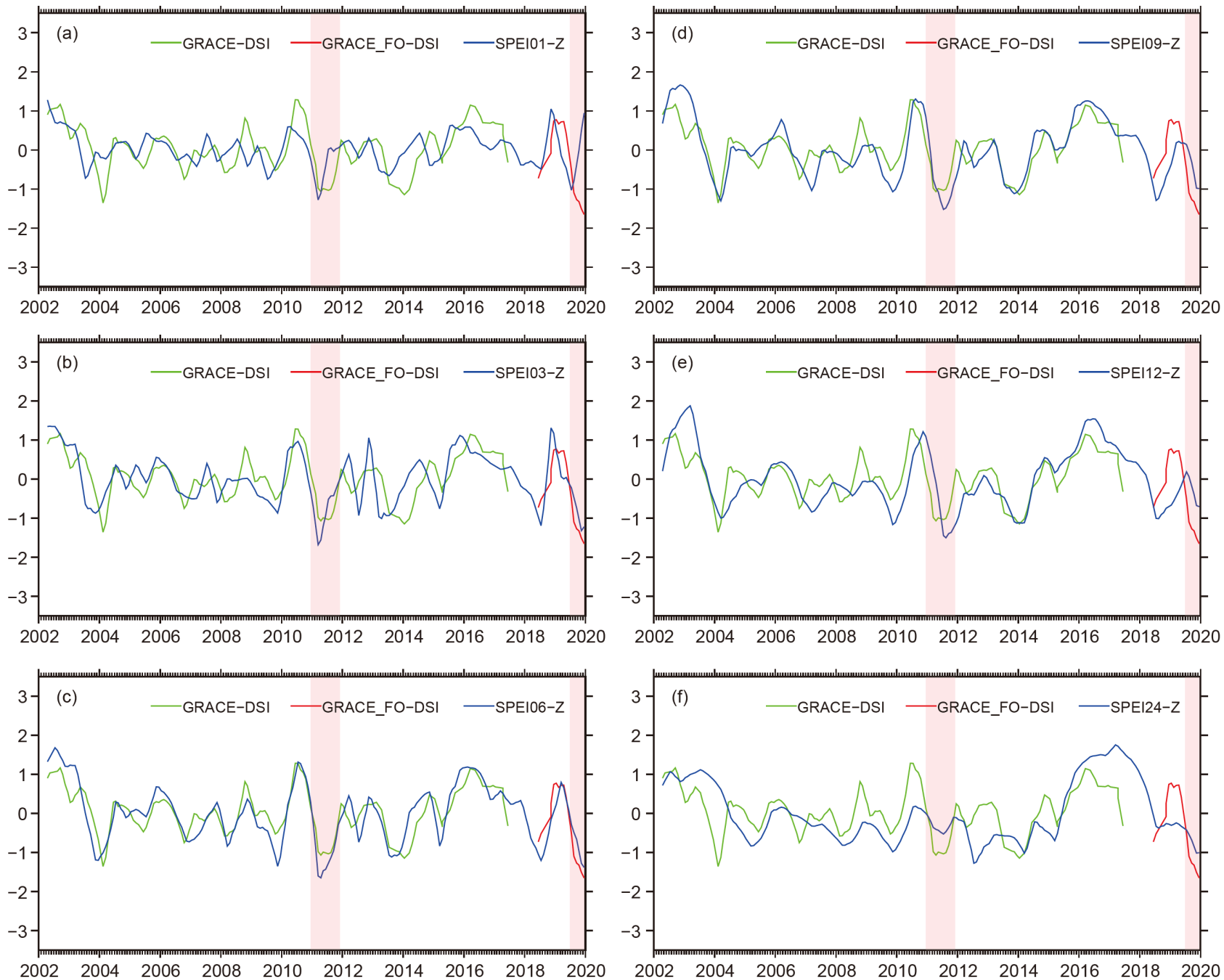

图 4 2002年4月 2019年12月湖北、湖南、江西、安徽四省的GRACE-DSI和SPEI-Z(时间尺度为1、3、6、9、12、24个月)时间序列. 利用小 波对时间序列做了低通滤波. 阴影区突出强调了发生在该区域的两次特大干旱事件的发生时间段

Figure 4 Time series of GRACE-DSI and SPEI-Z (with time scales of 1, 3, 6, 9, 12 and 24 months) in Hubei, Hunan, Jiangxi, and Anhui from April 2002 to December 2019. The time series were wavelet-based low-pass filtered. The shaded areas in highlight two major drought events in this region 
TWSA年际变化、GRACE-DSI和各个时间尺度SPEI-Z 的空间分布, 并结合全国气象干旱综合监测图结果分 析发现，2019年下半年重度或极端干旱区域主要集中 在湖北东部、湖南北部、江西北部、安徽南部等区域. 因此本研究选择在该区域内对这两类干旱指数进行区 域平均, 并对得到的时间序列进行比较分析. 图4显示 了2002年4月 2019年12月湖北、湖南、江西、安徽四 省区域平均的GRACE-DSI和SPEI-Z(时间尺度为 1 、

$3 、 6 、 9 、 12 、 24$ 个月)的时间序列, 发现该时间段内长 江中下游区域发生了两次特大干旱(图4红色阴影区 域), 第一次发生在2011年春夏, 第二次发生在2019年 夏秋.

从图4可以看出, GRACE-DSI和时间尺度为 $3 、 6$ 、 9个月的SPEI-Z的变化比较一致, 其中与SPEI06-Z的变 化无论是幅值还是相位上最为一致. GRACE-DSI与时 间尺度为 6 个月的SPEI-Z相关性最高, 达到 0.84 ; 与时 间尺度为 $3 、 9 、 12$ 个月的SPEI-Z相关性比较高, 分别 为 $0.69 、 0.77 、 0.64$; 与时间尺度为 24 个月的SPEI-Z相 关性比较低, 为 0.49 ; 与时间尺度为 1 个月的SPEI-Z相 关性最低, 为 0.42 . 这进一步说明GRACE-DSI能够反映 干旱的长期积累效应. 2018 2019年基于GRACE-FO卫 星观测计算的GRACE-DSI(图4中红色曲线)变化的峰 值延迟落后于SPEI01-Z/SPEI03-Z的峰值, 与SPEI-06的 峰值同步, 超前于SPEI09-Z/SPEI12-Z/SPEI24-Z的峰值. 对于2011年春夏和2019年夏秋发生的两次极端干旱时 间，基于GRACE卫星和GRACE-FO卫星观测结果分别 计算的GRACE-DSI与SPEI-03/SPEI-06/SPEI-09的时间 序列基本一致. 这说明基于模型进行数据修正的 GRACE-FO卫星与GRACE卫星，在区域大干旱监测方 面具有相当的能力.

\section{3 结论}

本研究基于GRACE-FO重力卫星观测的陆地水储 量异常和GRACE-DSI, 研究了2019年夏秋季发生在长 江中下游区域的极端干旱, 并与多种时间尺度的SPEI 和中国气象局发布的全国气象干旱综合监测图进行了 对比研究, 结论如下.

(1) 作为一项新的基于卫星的干旱指数, GRACEDSI很好地反映了 2019年夏秋季长江中下游区域极端 干旱的发生和发展过程. 过去 18 年的结果与 6 个月时间 尺度的SPEI指标相当, 展示出GRACE/GRACE-FO重力 卫星具有对极端干旱事件特征进行比较准确描述的 能力.

(2) 通过对比湖北、江西、安徽和湖南四省区域 平均的GRACE-DSI与各时间尺度SPEI-Z的时间序列, 发现GRACE-DSI与 6 个月时间尺度的SPEI-Z的时间序 列吻合最好, 相关性为 0.84 , 说明GRACE-DSI能够反映 干旱的长期积累效应.

(3) 通过比较长江中下游区域2011年春夏和2019 年夏秋两次极端干旱事件的监测, 发现基于GRACE重 力卫星和 GRACE-FO重力卫星观测资料计算的 GRACE-DSI均与 3、6、9个月时间尺度的SPEI-Z符合 较好, 说明GRACE与GRACE-FO前后两组重力卫星具 有相当的干旱监测能力.

目前，重力卫星的空间分辨率和时间分辨率还有 待于提高. 2021年, 我国将发射自主的重力卫星, 并开 始设计更优星座的重力卫星. 届时, GRACE-DSI能够更 快更好地描述水文干旱事件，为评估极端干旱对植物 生态、粮食生产和水资源的影响提供持续、准确可靠 的干旱监测信息.

致谢感谢国家气候中心提供每日全国气象干旱综合指数、西班牙奥拉德试验站(Estación Experimental de Aula Dei, 简称 EEAD)的Santiago Beguería等提供SPEI、美国德克萨斯大学空间研究中心(Center for Space Research, CSR)提供GRACE/ GRACE-FO卫星每月重力场球谐系数。文中涉及的中国地图经自然资源部地图技术审查中心审查, 审图号为 GS(2020) 4952号.

\section{参考文献}

1 Yang Q, Li M X, Zheng Z Y, et al. Regional applicability of seven meteorological drought indices in China (in Chinese). Sci China Earth Sci, 2017, 47: 337-353 [杨庆, 李明星, 郑子彦, 等. 7种气象干旱指数的中国区域适应性. 中国科学: 地球科学, 2017, 47: 337-353]

2 van Loon A F, Gleeson T, Clark J, et al. Drought in the Anthropocene. Nat Geosci, 2016, 9: 89-91

3 van Dijk A I J M, Beck H E, Crosbie R S, et al. The Millennium Drought in southeast Australia (2001-2009): Natural and human causes and implications for water resources, ecosystems, economy, and society. Water Resour Res, 2013, 49: 1040-1057

4 Tapley B D, Bettadpur S, Ries J C, et al. GRACE measurements of mass variability in the Earth system. Science, 2004, 305: 503-505 
5 Scanlon B R, Zhang Z, Save H, et al. Global evaluation of new GRACE mascon products for hydrologic applications. Water Resour Res, 2016, 52: 9412-9429

6 Feng W, Lemoine J M, Zhong M, et al. Terrestrial water storage changes in the Amazon basin measured by GRACE during $2002-2010$ (in Chinese). Chin J Geophys, 2012, 55: 814-821 [冯伟, Lemoine J M, 钟敏, 等. 利用重力卫星GRACE监测亚马逊流域2002-2010年的陆地水变 化. 地球物理学报, 2012, 55: 814-821]

7 Rodell M, Velicogna I, Famiglietti J S. Satellite-based estimates of groundwater depletion in India. Nature, 2009, 460: 999-1002

8 Chen J L, Wilson C R, Tapley B D, et al. 2005 drought event in the Amazon River basin as measured by GRACE and estimated by climate models. J Geophys Res, 2009, 114: 1-9

9 Zhong M, Duan J B, Houze X U, et al. Trend of China land water storage redistribution at medi-and large-spatial scales in recent five years by satellite gravity observations. Chin Sci Bull, 2009, 54: 816-821

10 Hasan E, Tarhule A, Hong Y, et al. Assessment of physical water scarcity in Africa using GRACE and TRMM satellite data. Remote Sens, 2019, 11: $1-17$

11 Feng W, Zhong M, Lemoine J M, et al. Evaluation of groundwater depletion in North China using the Gravity Recovery and Climate Experiment (GRACE) data and ground-based measurements. Water Resour Res, 2013, 49: 2110-2118

12 Joodaki G, Wahr J, Swenson S. Estimating the human contribution to groundwater depletion in the Middle East, from GRACE data, land surface models, and well observations. Water Resour Res, 2014, 50: 2679-2692

13 Sun Z, Zhu X, Pan Y, et al. Drought evaluation using the GRACE terrestrial water storage deficit over the Yangtze River Basin, China. Sci Total Environ, 2018, 634: 727-738

14 Chen J L, Wilson C R, Tapley B D, et al. Recent La Plata basin drought conditions observed by satellite gravimetry. J Geophys Res, 2010, 115: 112

15 Long D, Shen Y, Sun A, et al. Drought and flood monitoring for a large karst plateau in Southwest China using extended GRACE data. Remote Sens Environ, 2014, 155: 145-160

16 Yirdaw S Z, Snelgrove K R, Agboma C O. GRACE satellite observations of terrestrial moisture changes for drought characterization in the Canadian Prairie. J Hydrol, 2008, 356: 84-92

17 Yi H, Wen L. Satellite gravity measurement monitoring terrestrial water storage change and drought in the continental United States. Sci Rep, 2016, 6: $1-9$

18 Zhao M, Geruo A, Velicogna I, et al. A global gridded dataset of GRACE drought severity index for 2002-14: Comparison with PDSI and SPEI and a case study of the Australia Millennium Drought. J Hydrometeorol, 2017, 18: 2117-2129

19 Zhao M, Geruo A, Velicogna I, et al. Satellite observations of regional drought severity in the continental United States using GRACE-based terrestrial water storage changes. J Clim, 2017, 30: 6297-6308

20 Wang J, Jiang D, Huang Y, et al. Drought analysis of the Haihe river basin based on GRACE terrestrial water storage. Sci World J, 2014, 2014: 110

21 Cao Y, Nan Z, Cheng G. GRACE gravity satellite observations of terrestrial water storage changes for drought characterization in the arid land of Northwestern China. Remote Sens, 2015, 7: 1021-1047

22 Cheng M, Ries J. The unexpected signal in GRACE estimates of $C_{20}$. J Geod, 2017, 91: 897-914

23 Sun Y, Riva R, Ditmar P. Optimizing estimates of annual variations and trends in geocenter motion and $J_{2}$ from a combination of GRACE data and geophysical models. J Geophys Res Solid Earth, 2016, 121: 8352-8370

24 Swenson S, Chambers D, Wahr J. Estimating geocenter variations from a combination of GRACE and ocean model output. J Geophys Res, 2008, 113: $1-12$

25 Swenson S, Wahr J. Post-processing removal of correlated errors in GRACE data. Geophys Res Lett, 2006, 33: 1-4

26 Jekeli C. Alternative methods to smooth the Earth's gravity field. Doctor Dissertation. Ohio: The Ohio State University, 1981

27 Wahr J, Molenaar M, Bryan F. Time variability of the Earth's gravity field: Hydrological and oceanic effects and their possible detection using GRACE. J Geophys Res, 1998, 103: 30205-30229

28 Swenson S, Wahr J. Multi-sensor analysis of water storage variations of the Caspian Sea. Geophys Res Lett, 2007, 34: 1-5

29 Vicente-Serrano S M, Beguería S, López-Moreno J I. A multiscalar drought index sensitive to global warming: The standardized precipitation evapotranspiration index. J Clim, 2010, 23: 1696-1718

30 Palmer W C. Meteorological Drought Research Paper No. 45. Washington DC: US Weather Bureau, 1965

31 MKee T B, Doesken N J, Kleist J. The relationship of drought frequency and duration to time scales. In: 8th Conference on Applied Climatology, Anaheim, California, 1993. 179-184

32 Beguería S, Vicente-Serrano S M, Reig F, et al. Standardized precipitation evapotranspiration index (SPEI) revisited: Parameter fitting, evapotranspiration models, tools, datasets and drought monitoring. Int J Climatol, 2014, 34: 3001-3023 
33 Vicente-Serrano S M, Beguería S, Lorenzo-Lacruz J, et al. Performance of drought indices for ecological, agricultural, and hydrological applications. Earth Interact, 2012, 16: 1-27

34 Liang F, Liu D D, Xu H M, et al. Comparison of drought variation in Northeast China from 1961 to 2009 by using three drought index datasets (in Chinese). Res Soil Water Conserv, 2018, 25: 183-189 [梁丰, 刘丹丹, 徐红梅, 等. 不同干旱指数集对1961-2009年东北地区干旱描述的比较. 水土保持研究, 2018, 25: 183-189]

\section{补充材料}

图S1 2019年7 12月全国气象干旱综合指数

图S2 2019年7 12月时间尺度为1、3、9、12、24个月的SPEI-Z的空间分布

本文以上补充材料见网络版csb.scichina.com. 补充材料为作者提供的原始数据, 作者对其学术质量和内容负责. 


\title{
Monitoring the extreme drought in the middle and lower reaches of the Yangtze River in 2019 from GRACE-FO satellites
}

\author{
Yanhong Ran ${ }^{1,2}$, Min Zhong ${ }^{1,2^{*}}$, Wei Chen ${ }^{1,2,3}$, Yulong Zhong ${ }^{4}$ \& Wei Feng ${ }^{1}$ \\ ${ }^{1}$ State Key Laboratory of Geodesy and Earth's Dynamics, Innovation Academy for Precision Measurement Science and Technology, Chinese Academy \\ of Sciences, Wuhan 430077, China; \\ ${ }^{2}$ School of Earth and Planetary Sciences, University of Chinese Academy of Sciences, Beijing 100049, China; \\ ${ }^{3}$ School of Earth Sciences, the Ohio State University, Columbus 43210, USA; \\ ${ }^{4}$ School of Geography and Information Engineering, China University of Geosciences (Wuhan), Wuhan 430074, China \\ * Corresponding author, E-mail: zmzm@asch.whigg.ac.cn
}

In the summer and autumn of 2019, an extreme drought lasting 0.5 year in the middle and lower reaches of the Yangtze River had a major impact on local agricultural production and the ecological environment. Traditionally, drought severity assessment relies on drought-related parameters observed by in situ measurements, such as precipitation, evapotranspiration, runoff, and soil moisture. In the past two decades, GRACE/GRACE-FO gravity satellite data have been widely used to estimate global and regional terrestrial water storage anomalies (TWSA), but there are still limited studies on the quantitative assessment of the severity of drought using GRACE/GRACE-FO data. The objective of this study was to analyse the drought severity in the middle and lower reaches of the Yangtze River in the summer and autumn of 2019 using GRACE/GRACE-FO data and to compare our estimates with the traditional drought index.

The GRACE-based drought severity index (GRACE-DSI) is a monthly global drought severity index based on the TWSA from the GRACE/GRACE-FO (GRACE-TWSA). In this study, we used spherical harmonic (SH) products from the GRACE/GRACE-FO to obtain the TWSA. GRACE data processing includes replacing the degree- 1 and $C_{20}$, removing the 2004-2009 mean SH, filtering to reduce correlated errors, Gaussian smoothing, calculating the equivalent water layer thickness on $1^{\circ} \times 1^{\circ}$ grids, and correcting leakage errors with scale factors. We then calculated the GRACE-DSI based on the GRACE-TWSA with the trend and seasonal cycles removed. To ensure consistency, we processed the standardised precipitation evapotranspiration index (SPEI) similar to the GRACE data and standardised the new SPEI as the SPEI-Z.

Our results indicated that the GRACE-DSI can successfully monitor the occurrence and development of drought in the middle and lower reaches of the Yangtze River in spatiotemporal domains. The GRACE/GRACE-FO successfully detected the extreme drought event that occurred in the east of Hubei, north of Jiangxi, and south of Anhui during the summer and autumn of 2019. In July, the arid region was located in the north of the Yangtze River basin, including Henan and Shandong provinces. In August, the drought intensified and moved south to the middle and lower reaches of the Yangtze River, reaching a maximum in September, especially in Hubei, Jiangxi, and Anhui provinces. The drought was weakened in October, but intensified again in November and December and expanded through the middle and lower reaches of the Yangtze River to the coastal regions, such as Fujian and Guangzhou provinces.

The mean time series of the GRACE-DSI over Hubei, Jiangxi, Anhui, and Hunan provinces showed good agreement with the SPEI-Z in both amplitude and phase on the six month time scale (SPEI06-Z) with a correlation coefficient of 0.84. The time series of the GRACE-DSI and SPEI06-Z both clearly showed the extreme drought events that occurred in Hubei, Jiangxi, Anhui, and Hunan provinces during the spring and summer of 2011 and the summer and autumn of 2019. Our results also indicate that the GRACE-FO has the same drought monitoring capability as the GRACE.

\section{GRACE-FO, GRACE-DSI, drought index, the middle and lower reaches of the Yangtze River}

doi: $10.1360 /$ TB-2020-0375 